Eskişehir Osmangazi Üniversitesi

Sosyal Bilimler Dergisi

Nisan 2019, 20 (Özel Sayı), sayfa aralığı

DOI: 10.17494/ogusbd.

\title{
Sınıf Öğretmeni Adaylarının Diksiyona ỉiş̧kin Görüşleri
}

\author{
Emel GÜVEY AKTAY*
}

Sınıf Öğretmeni Adaylarının Diksiyona İlişkin Görüşleri

Özet

Doğru ve güzel konuşma becerisi, iletişimin temelini oluşturmaktadır. Küçük yaşlardan itibaren ana dilini doğru ve güzel konuşabilme, aile yaşamının dışında okul ortamında şekillenen ve öğretmenlerin rol model olduğu bir beceridir. Bu nedenle, sınıf öğretmenlerinin ve sınıf öğretmeni adaylarının diksiyon konusunda özenli ve yeterli olması gerekmektedir. Bu araştırmanın amacı; sınıf öğretmeni adaylarının diksiyon konusundaki görüşlerini belirlemektir. Betimsel modelde gerçekleştirilen araştırmada veriler açık uçlu sorulardan oluşan anket yoluyla toplanmıştır. Araştırmaya 2015-2016 öğretim yılı bahar döneminde bir devlet üniversitesinin Sınıf Öğretmenliği Programı 3. sınıfında öğrenim gören 55 öğretmen adayı katılmıştır. Araştırma verileri betimsel analiz yoluyla çözümlenmiştir. Araştırma sonuçlarına göre öğretmen adaylarının, diksiyonun öğretmenlik için önemli olduğu, kendilerini geliştirmeleri ve bu konuda bir eğitim alınması gerektiği görüşünde oldukları ortaya çıkmıştır.

\author{
The Opinions of Primary School Teacher Candidates \\ Regarding Diction \\ Abstract
}

Correct and elocution skills are the basis of communication. From an early age, besides families, speaking the mother tongue accurately and beautifully is a skill that is shaped by the school environment and, and with teachers becoming the role model. For this reason, the primary school teachers, and the primary school teacher candidates should be careful and sufficient about the diction. The purpose of this research is to determine the opinions of the primary school teacher candidates on diction. The data were collected through a questionnaire consisting of openended questions, and the research conducted is a descriptive model. In the spring term of 2015-2016 academic year 55 primary school teacher candidates from the 3rd grade of a public university program participated in the study. Research data were analyzed by descriptive analysis. According to the results of the research, it was found out that prospective teachers think that diction is important for teaching, and they should develop themselves and they should receive training in this subject.
Anahtar Kelimeler: Diksiyon, Güzel Konuşma, Türkçe Öğretimi, Sınıf Öğretmenliği
Key Words: Diction, Elocution, Teaching Turkish, Primary School

\section{Giriş}

Bireylerin iletişim kurabilmeleri ve toplumdaki diğer bireylerle anlaşabilmeleri için gerekli olan temel dil becerilerinden biri konuşmadır. Konuşma, duyma ve dinleme yoluyla ortaya çıkan sesletimlerin sözel olarak ifade edilmesine ve anlamanın gerçekleşmesine yardımcı bir beceridir. Konuşmanın nitelikli ve anlaşılabilir olması, bireyler arasındaki

\footnotetext{
*Emel GÜVEY AKTAY, Dr. Öğr. Üyesi., Muğla Sıtkı koçman Üniversitesi, Temel Eğitim Bölümü, emelguveyaktay@mu.edu.tr , ORCID ID orcid.org / 0000-0002-5659-8924
} 


\section{Emel GÜVEY AKTAY}

iletişimi güçlendirmektedir. Sözel iletişimin, toplumları bir araya getiren ya da toplumlarda ayrılıklara neden olan bir etmen olduğu düşünüldüğünde, konuşma becerisinin geliştirilmesi önemlidir.

Konuşma, psikolojik süreçleri içeren ve etkileşim gerektiren oldukça karmaşık bir süreçtir Thornbury (2012). Zihinde başlayan ve düşüncelerin sözle ifade edilmesiyle tamamlanan bir süreç olan (Güneş, 2007, s. 95) konuşma, bir başka tanıma göre düşünceleri, duyguları ve bilgileri, seslerden oluşan dil aracılığıyla karşıdakine iletmek, açıklamak ve dışavurmaktır (Taşer, 2000, s. 27). Toplumdaki bireylerin diğer bireylerle anlaşma yollarından en önemlisi konuşmadır (Erdem ve Deniz, 2008). Küçük yaşlardan itibaren başlayan ve sürekli gelişen konuşma becerisi, aynı zamanda bireylerin öğrenme, ifade etme ve anlama konusunda gelişimlerini de desteklemektedir. Doğru ve etkileyici bir konuşmanın, bireylerin sosyal ve akademik yaşamlarını kolaylaştırdığını ve bireylerin anlatmak istediklerini net bir biçimde karşıdakine aktarmalarını sağlayan yaşam boyu beceriler arasında yer aldığını söylemek mümkündür. Bireylerin doğumundan itibaren çevresindeki sesleri duyarak ve onları taklit ederek konuşmaya çalıştığı düşünüldüğünde doğru ve güzel konuşma, rol modeller aracılığıyla yaygınlaştırılmakta ve geliştirilebilmektedir. Bu noktada önce ailede başlayan ve sonra formal bir ortam olan okul ortamında gelişen konuşma becerisinde, küçük yaştaki çocuklara rol model olacak öğretmenlerin, doğru ve etkili bir konuşmaya sahip olması gerekmektedir.

Konuşma, öğretmenlerin sınıf ortamında öğrenme-öğretme sürecini yürütebilmek için en sık kullandıkları iletişim kanalıdır. Öğretmenin sınıf ortamında Türkçeyi doğru ve etkili kullanması, dersin daha iyi anlaşımasının yanı sıra öğrencilerin konuşmalarındaki hataların düzeltilmesinde de etkili yollardan biridir (Katrancı, 2014). Canbulat ve KutlucaCanbulat (2015) çalışmalarında, Avusturya'da öğretmen adayının seçimi için gerçekleştirilen sınavlarda öğretmen adaylarının dil hâkimiyetini belirlemeye yönelik 'sunum' ve 'tanıtım’ başlığı altında bir sınava girdiklerine değinmişlerdir. Bu sınavda Schaarschmidt (2005) tarafından belirlenen ve ilgili komisyon tarafından düzenlenen, öğretmen adaylarının diksiyon, boğumlanma, nefes kontrolü, akıcı konuşma vb. özelliklerinin gözlemlenmesi maddeleri yer almaktadır. Bu bağlamda ele alındığında öğretmen adayları için gerekli olan diksiyon ve konuşmanın, öğretmenlik mesleğini yaparken ayrıca önemli olduğunu söylemek mümkündür. Özellikle ana dilinin geliştirilmesi bağlamında temel oluşturan ve ilkokulda okuma ve yazma dil becerileriyle desteklenen konuşma becerisinde, özellikle sınıf öğretmenleri etkin bir role sahiptir. Bu nedenle sınıf öğretmenlerinin diksiyon konusunda yetkin olması gerekmektedir. 
Diksiyon, çeşitli sesler kullanılarak, vurgu, tonlama ve hız gibi yapı özellikleri doğrultusunda, konuşmanın bir müzikal yapı biçimine gelmesidir (Halvaşi, 2015, s. 868). Bir başka tanıma göre diksiyon; konuşurken sözcüklerin seçimi ve düzeni anlamına gelen ve bir dilin ses özelliklerine göre doğru ve güzel seslendirilmesi becerisidir (İnan, 2016, s. 13). Diksiyonda soluk alma çok önemlidir. Konuşma eğitiminde kişilere doğru nefes almayı öğretmek gerekmektedir (Bağcl-Ayrancı, 2016).

Milli Eğitim Bakanlığı tarafından 2017 yılında güncellenen ve öğretmenlerin sahip olması gereken bilgi, beceri ve tutumların yer aldığı Öğretmenlik Mesleği Genel Yeterlikleri ve bunun bir diğer parçası olan Özel Alan Yeterlikleri kapsamında dilin etkili ve güncel kullanılması ve iletişime yönelik maddeler yer almaktadır. Bir öğretmenin iletişim ve işbirliği başlığı altında sahip olması gereken genel yeterlikler incelendiğinde, "Türkçeyi kurallarına uygun ve etkili biçimde kullanır." ifadesi yer almaktadır. Bunun yanı sıra Sınıf Öğretmeni Özel Alan Yeterlikleri kapsamında da bir sınıf öğretmeninin, öğrencilerinin Türkçeyi doğru, güzel ve etkili kullanma becerilerini geliştirebilmeleri ve bu konuda öğrencilerine rol model olabilmelerine ilişkin yeterlik maddeleri yer almaktadır. Aynı zamanda bir sınıf öğretmeninin, öğrencilerinin etkili iletişim kurmaları ve onların beden dilini doğru ve etkili kullanmaları bağlamında da yeterlik kazanmaları gerektiği vurgulanmaktadır. Bu açıdan ele alındığında, sınıf öğretmenlerinin Türkçeyi doğru ve güzel kullanmalarının, bunu öğrencilerine aktarırken aynı zamanda etkili bir iletişim kurmalarında gerekli olan güzel konuşma ve beden dili doğru kullanmalarının, belirlenen standartlar düzeyinde yeterli olması gerekmektedir.

Diksiyonu düzgün olan bir öğretmen, öğrencilerine aktardığı her konunun daha iyi anlaşılması sağlayacaktır. Bu bağlamda öğretmen adaylarının hizmet öncesi eğitimden itibaren diksiyon açısından eksik yönlerinin farkında olarak kendilerini bu konuda geliştirmeleri oldukça önemlidir. Bu önem doğrultusunda gerçekleştirilen araştırmada, ileride öğretmenlik mesleğini yapacak olan sınıf öğretmeni adaylarının görüşleri ele alınmıştır.

\subsection{Araştırmanın Amacı}

Bu araştırmanın amacı; sınıf öğretmeni adaylarının diksiyona ilişkin görüşlerini ortaya koymaktır. Bu amaç doğrultusunda sınıf öğretmeni adaylarının, diksiyona ilişkin farkındalıkları, gereksinimleri, okuma ve konuşma sırasında yaptıkları yanlışlıklar belirlenmiştir. Araştırmada şu sorulara yanıt aranmıştır:

- S S S S Söığretmeni adaylarına göre diksiyonun önemi ve öğretmenlik için yararı nedir?

- S Sınıf öğretmeni adayları diksiyon konusunda kendilerini nasıl değerlendirmektedir?

- S S S S Söı̆retmeni adayları diksiyon konusunda nasıl bir eğitim istemektedir? 
- S Sınıf öğretmeni adaylarının diksiyon konusunda yaptıkları yanlışlıklar nelerdir?

\section{Yöntem}

Araştırma, temel nitel araştırma yaklaşımıyla gerçekleştirilmiştir. Temel nitel araştırmalar, tüm disiplin alanlarında uygulanabilen ve eğitimde yaygın kullanımı olan nitel araştırma biçimleridir. Veriler; görüşmeler, gözlemler ya da doküman analizi yoluyla toplanır. Tekrarlayan örüntüler belirlenerek yapılan analizler doğrultusunda bulgular, veri tarafından desteklenen temalardan oluşmaktadır (Merriam, 2013, s. 23).

\subsection{Katılımcılar}

Katılımcıların belirlenmesinde amaçlı örnekleme yöntemlerinden ölçüt örnekleme kullanılmıştır. Ölçüt örneklemede temel anlayış, önceden belirlenmiş ölçütleri karşılayan durumların çalışılmasıdır. Ölçüt ya da ölçütler, araştırmacı tarafından oluşturulabileceği gibi daha önceden hazırlanmış bir ölçüt listesi de kullanılabilmektedir (Yıldırım ve Şimşek, 2013, s. 140).

Bu araştırmada katılımcıların seçilmesinde, araştırmaya katılan öğretmen adaylarının araştırmanın yapıldığı dönemde Türkçe Öğretimi dersini almış olmaları ve araştırmaya gönüllü katılmayı kabul etmeleri temel ölçüt olarak benimsenmiştir. Araştırmaya 20152016 eğitim öğretim yılı bahar döneminde, bir devlet üniversitesinin Eğitim Fakültesi Sınıf Öğretmenliği Programı 3. sınıfında öğrenim gören 55 öğretmen adayı katılmıştır. Katılımcılara ilişkin veriler Tablo 1'de sunulmuştur.

Tablo 1. Araştırmaya Katılan Öğretmen Adaylarına İlişkin Veriler

\begin{tabular}{cccccc}
\hline \hline \multicolumn{2}{c}{ Cinsiyet } & $\begin{array}{c}\text { Öğrenim Gördüğ̈̈ } \\
\text { Sınıf Düzeyi }\end{array}$ & Kişi sayısı & \multicolumn{2}{c}{ Diksiyon Eğitimi Alma } \\
\hline Kadın & Erkek & 3. sınıf & 53 & Evet & Hayır \\
& & & & & 42 \\
45 & 10 & 4. sınıf & 2 & & \\
\hline
\end{tabular}


Tablo 1'de görüldüğü gibi öğretmen adaylarından 2'si dersi alttan almaktadır. Araştırma 55 katılımcı ile gerçekleştirilmiştir. 45'i kız, 10'u erkek olan katılımcıların 13'ü diksiyonla ilgili bir eğitim aldıklarını; 42'si ise diksiyonla ilgili herhangi bir eğitim almadıklarını belirtmişlerdir.

\subsection{Veri Toplama Aracı}

Araştırma verileri açık uçlu anket formu yoluyla elde edilmiştir. Anketin ilk bölümünde öğretmen adaylarının kişisel özelliklerini belirlemeye yarayan sorular yer almakta; ikinci bölümde ise diksiyonla ilgili 4 açık uçlu soru ve 1 kapalı uçlu soru bulunmaktadır. Anketin geçerlik çalışması için uzman görüşüne başvurulmuş ve 4 öğretmen adayı ile ön denemesi yapılmıştır. Uzman görüşleri ve ön deneme sonuçlarına göre anket yeniden düzenlenmiş ve uygulamaya hazır duruma getirilmiştir.

Anket, katılımcıların uygun zamanında dağıtılmış ve gönüllü olarak araştırmaya katılmak isteyen öğretmen adaylarına verilmiştir. Veriler bizzat araştırmacı tarafından öğretmen adaylarının bulunduğu sınıfta toplanmıştır. Bu süreçte öğretmen adaylarına kendi bakış açılarını ve görüşlerini tam anlamıyla yansıtabilmelerini sağlamak amacıyla yeterli süre tanınmıştır.

\subsection{Verilerin Analizi}

Araştırma verilerinin çözümlenmesinde betimsel analiz tekniği kullanılmıştır. Betimsel analizde elde edilen veriler, önceden belirlenen temalara göre özetlenmekte ve yorumlanmaktadır (Yıldırım ve Şimşek, 2016). Buna göre, araştırma sorularına ilişkin verilen yanıtlar doğrultusunda kodlamalar yapılmış ve temalar, araştırma soruları doğrultusunda oluşturulmuştur.

Nitel araştırmalarda iç geçerlik yerine "inandırıcılık"; dış geçerlik yerine "teyit edilebilirlik" kavramları kullanılmaktadır (Lincoln ve Guba, 1985). Erlandson ve diğerleri (1993), teyit edilebilirlik için 'teyit incelemesi' stratejisinin kullanılması gerektiğini belirtmişlerdir (Yıldııım ve Şimşek, 2016). Araştırmanın inandırıcılığı kapsamında, verilerden elde edilen temalar, iki alan uzmanının görüşüne sunulmuştur. Uzman görüşleri doğrultusunda temalar belirlenmiş ve görüş ayrılığına düşülen temalar yeniden düzenlenmiştir. Bunun yanı sıra teyit incelemesi aşamasında araştırmacı, ulaştığı sonuçları ham verileriyle karşılaştırmak amacıyla yine bir alan uzmanının incelemesine sunmuştur.

\section{Bulgular}

Araştırma sonucunda elde edilen bulgular, "Diksiyonun Önemi”, "Öğretmenlikte Diksiyon”, "Özdeğerlendirme" ve "Eğitim Alma” olmak üzere dört başlıkta toplanmıştır. Katı- 


\section{Emel GÜVEY AKTAY}

lımcıların kapalı uçlu sorulara verdikleri yanıtlar ise "Seslendirmede Yapılan Hatalar" kapsamında ele alınmıştır. Öğretmen adaylarından elde edilen verilerin sunulmasında öğretmen adaylarına kod isim verilmiştir. Verilen kod isimler, Ö1, Ö2 vb. biçimde sayılarla ifade edilmiştir.

\subsection{Diksiyonun Önemi}

Öğretmen adaylarının diksiyonun önemine ilişkin görüşlerini belirlemek amacı ile "Sizce diksiyonun önemi nedir?" sorusu yöneltilmiştir. Diksiyonun önemi temasına ilişkin 3 alt tema ortaya çıkmıştır. Bu alt temalar Şekil 1'de gösterilmiştir.
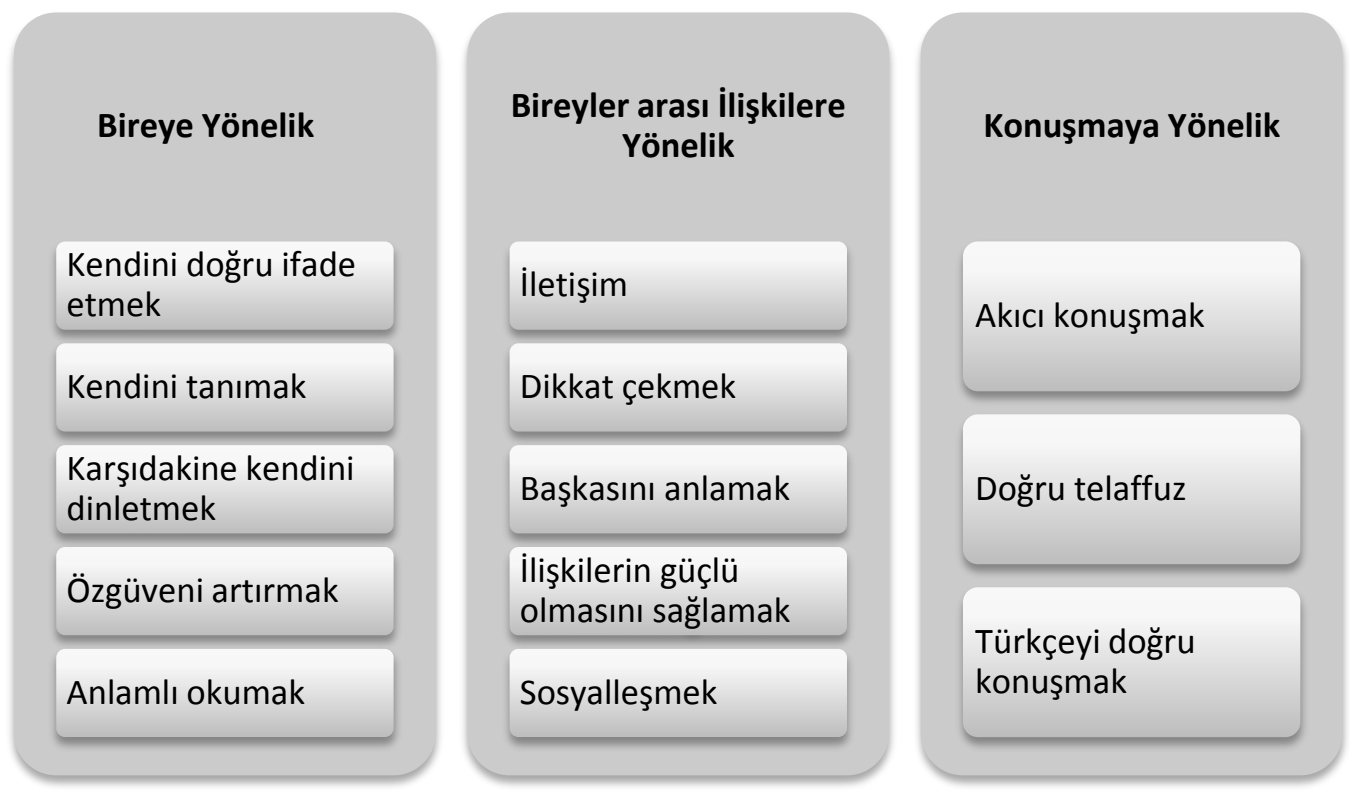

Şekil 1. Diksiyonun Önemine illişkin Alt Temalar

Şekil 1'de öğretmen adaylarının diksiyonun önemine ilişkin görüşlerinden oluşan başlıklar görülmektedir. Araştırmanın amacı doğrultusunda ele alınan temada öğretmen adaylarının, diksiyonun bireylere ve diğer bireylerle olan ilişkisine olumlu etkileri olduğunu; aynı zamanda konuşma becerisini geliştirdiği görüşünde oldukları belirlenmiştir. 
Diksiyonun bireyler için önemine ilişkin olarak Ö3: "Karşı tarafın bizim söylediklerimizi, anlatmak istediğimiz gibi tam ve net bir şekilde anlayabilmesi için..." şeklinde ifade ederek, "kendini doğru ifade etme" konusuna vurgu yaparken; Ö12: “...Karşımızdakine bir şey anlatırken bizi dinlemekten sıkılmaz." diyerek "karşıdakine kendini dinletmek" konusuna değinmiştir. Öğretmen adaylarından Ö40: "Diksiyon, bir kişinin duruşunu, kendine güvenini, bakış açısını gösterir." diyerek diksiyonun bireylerin özgüvenlerini artırdığını belirtmiştir. Bunun yanı sıra Ö48, diksiyonun kişinin kendini tanımasını sağladığını; Ö55 ise diksiyonun kişinin kendini geliştirmeye yardımcı olduğunu ifade etmiştir. Ö15 ise: "Anlayarak, hissederek ve hissedileni dinleyicilere de aktararak okumayı sağlar." ifadesiyle anlamlı okumaya değinmiştir. Yazılı ifadelerle verilen yanıtlar doğrultusunda, öğretmen adaylarına göre diksiyonun, bireyin gelişimi için yararlı ve ele alınması gereken bir konu olduğu söylenebilir.

Öğretmen adayları, diksiyonun bireylerin diğer bireylerle olan ilişkilerinde de yararlı bir etkinlik olduğunu ifade etmişlerdir. Buna ilişkin olarak Ö23: "Diksiyonu düzgün kullanan insan, düzgün bir iletişim kurar." diyerek diksiyonun iletişim kurmada önemli olduğunu ifade etmiştir. Ö52: "Diksiyonu düzgün bir kişi toplum tarafından beğenilir." şeklinde görüşünü ifade etmiştir. Ö1 ise: "...Statü sahibi insanlarda diksiyon ne kadar düzgün olursa, kişinin hayatı o derece kolaylaşır ve itibar sahibi olur." diyerek diksiyonun toplum içinde dikkat çeken kişi olmaya yardımcı olduğunu vurgulamıştır. Öğretmen adaylarından Ö6: "Diksiyon, hem kendini anlatmada hem de başkasını anlamada çok önemlidir." diyerek başkasını anlayabilme noktasında diksiyonun önemli olduğunu ifade etmiştir. Bunun yanı sıra Ö14, diksiyonun ilişkileri güçlendiren bir etkiye sahip olduğunu ifade ederken; Ö48 diksiyonun sosyalleşmeye yardımcı olduğunu belirtmiştir.

Öğretmen adayları diksiyonun konuşma açısından da önemli olduğunu ifade etmiştir. Buna ilişkin olarak Ö12: "Kelimeleri doğru telaffuz ederiz... Akıcı konuşmamıza fayda să̆lar." diyerek, diksiyonun doğru telaffuz ve akıcı konuşma üzerindeki önemini vurgulamıştır. Ö9: "Kelimeleri yutmadan, şive kullanmadan konuşmamızı sağlar." şeklindeki ifadesiyle diksiyonun, Türkçeyi doğru kullanmaya yardımcı olduğunu belirtmiştir. Verilen yanıtlarda sınıf öğretmeni adaylarının diksiyonu, kendileri için önemli ve yararlı buldukları belirlenmiştir.

\section{2. Öğretmenlikte Diksiyon}

Öğretmen adaylarına ikinci olarak "Öğretmenlik mesleği açısından, diksiyonun sizce ne gibi yararlar sağlayacağını düşünüyorsunuz?” sorusu yöneltilmiştir. Buna ilişkin olarak öğretmen adaylarının görüşleri Şekil 2'de belirtilmiştir: 
Emel GÜVEY AKTAY

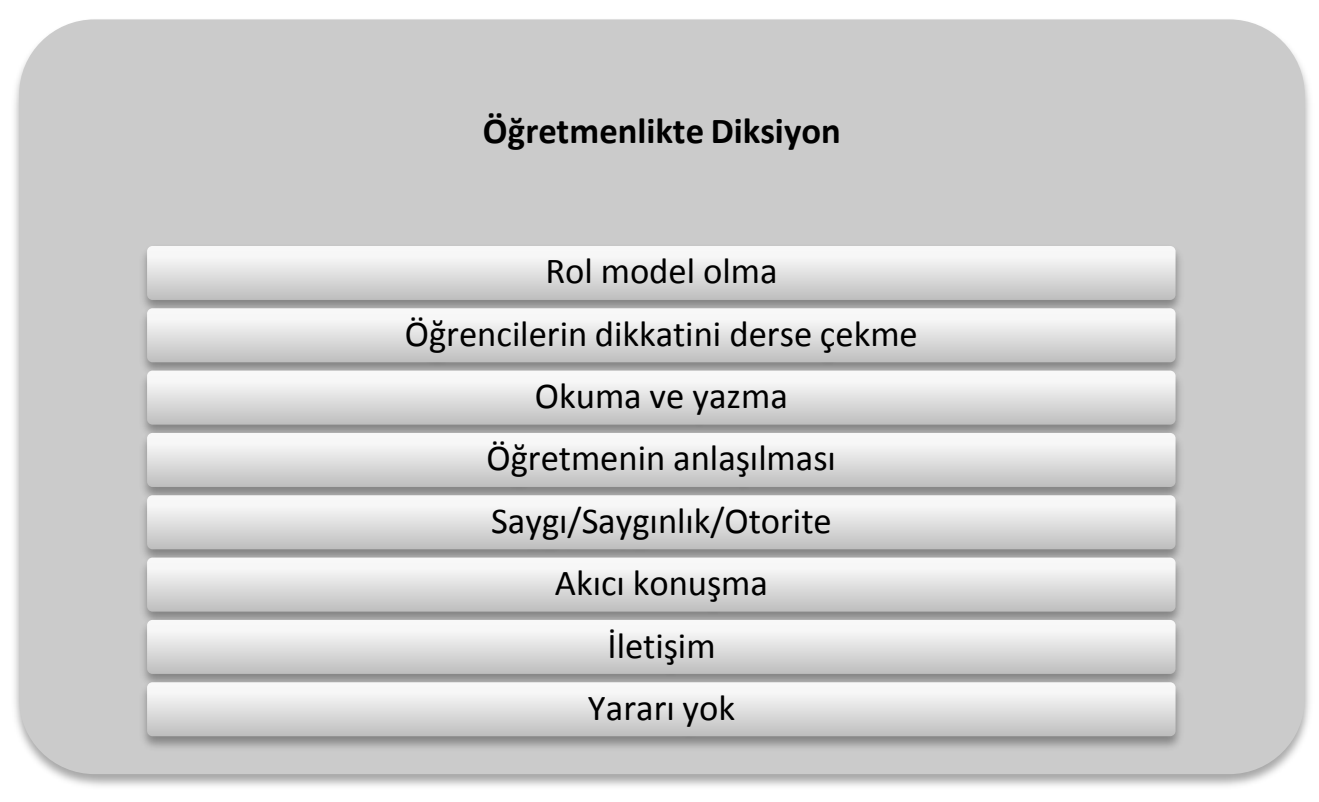

Şekil 2. Öğretmenlikte Diksiyon Teması

Öğretmen adaylarından Ö19: “Öğrencilere rol model olduğumuz için, onlara iyi bir örnek olmak için ve düzgün iletişim için bize yararlar sağlar." şeklinde görüşünü ifade ederek diksiyonun öğretmen için rol model olma ve iletişim kurma konularında önemli olduğunu belirtmiştir. Derste anlatılan konuların anlaşılmasına ilişkin olarak Ö25: "Öğrencilerin anlatılan konuları anlamasını kolaylaştırarak, öğrencinin ilgisini çekebilmemizi sağlar." şeklinde görüşünü ifade etmiştir. Bu bağlamda belirtilen görüş diksiyonun, öğretmenin anlaşılmasını ve öğrencinin dikkatini derse çekmesini sağladığını belirtmektedir.

Öğretmen adayları, okuma ve yazma konusunda diksiyonun önemini vurgulayan ifadeler yazmışlardır. Buna ilişkin olarak Ö27: "Şiir okurken kolaylık sağlar. Düz metinlerin daha anlaşılır olmasını sağlar." diyerek öğretmen açısından metinlerin okunması konusunda diksiyonun yararlı olacağını ifade etmiştir. Ö32 ise okuma ve yazma konusunu, diksiyonun öğretmenin harf öğretiminde işine yarayacağı görüşüyle ele almıştır. Bu görüşünü "Harf öğretimlerinde işimizi kolaylaştıracağını düşünüyorum." şeklinde ifade etmiştir. Öğretmen adaylarının bir kısmı, diksiyonu iyi kullanan öğretmenin sınıf hâkimiyetini sağlayacak otoritesi olabileceği ve bulunduğu çevrede saygı duyacağı görüşüne sahiptir. Bu konuyla ilgili olarak Ö41: "Sınıfa hâkim olma konusunda yararlı olacaktır." diye görüşünü belirtirken; Ö1: "...Insanlar ciddiye alır ve saygı duyar." diyerek dış çevreden gelen saygı ve öğrenciye yönelik otorite kavramlarını ele almışlardır. Ö7 ise: "Sınıfa hâkimiyet 
kurmaya yarayacağı gibi toplumda saygınlık kazandırmaya da yarayacaktır." diye belirterek saygınlık ve otorite kavramlarını bir arada değerlendirmiştir.

Öğretmen adaylarından Ö51, diksiyonun bir yararı olmadığı düşüncesindedir. Bu düşüncesini: "Herhangi bir yararı olduğunu düşünmüyorum. Çünkü bu eğitim sokakta, evde uygulanabilecek bir sistem değildir. Havada kalacak bir uygulama olarak kalacaktır. Bir öğretmen gittiği her köydeki geleneksel kelimeleri kullanmalıdır." diyerek, diksiyonun öğretmenlik yaşamında şive konusunda yetersiz kalacağı yönünde bir bakış açısına sahip olduğu söylenebilir.

\section{3. Özdeğerlendirme}

Öğretmen adaylarına üçüncü soru olarak "Konuşurken ya da okurken, kendi diksiyonunuz konusunda ne düşünüyorsunuz? (Diksiyon açısından kendinizin olumlu ya da eksik yönleri sizce nelerdir?) sorusu yöneltilmiştir. Öğretmen adaylarının kendilerini değerlendirmelerine ilişkin görüşleri Şekil 3'te belirtilmiş̧ir.
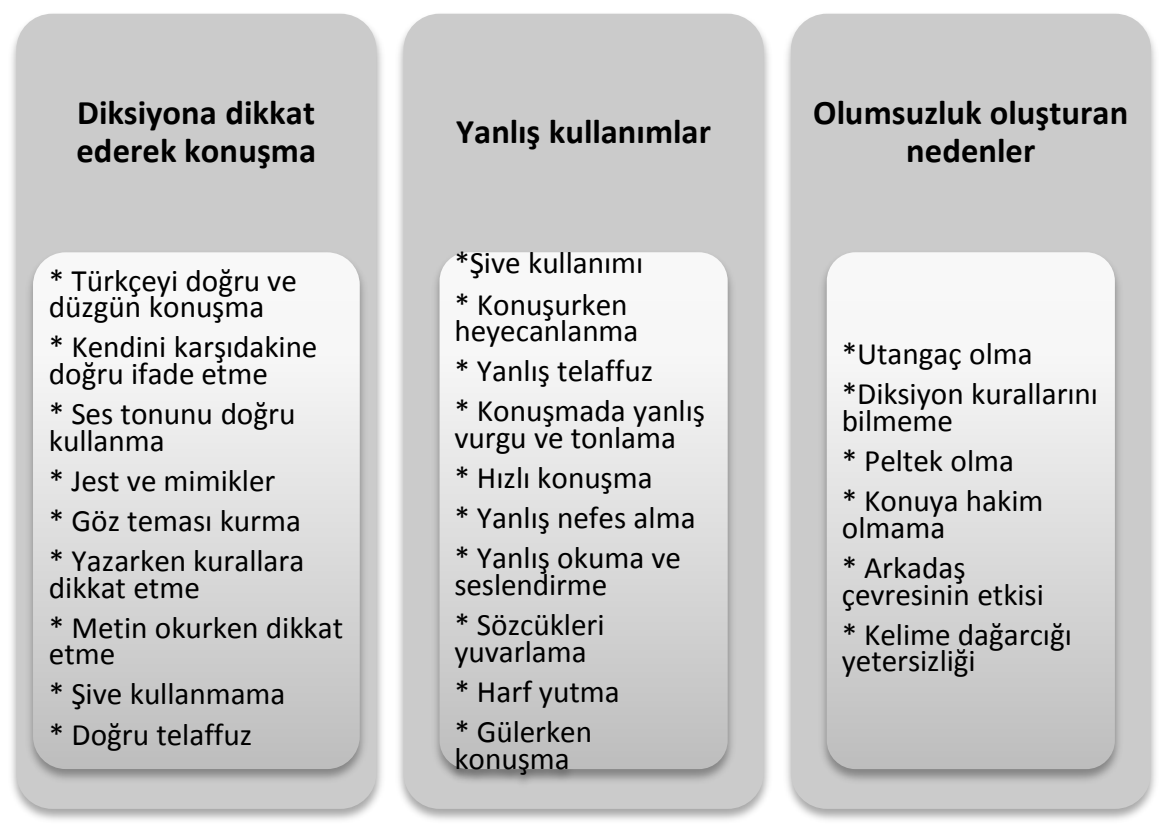

Şekil 3. Özdeğerlendirme Teması

Şekil 3 incelendiğinde, öğretmen adaylarının kendilerini olumlu olarak değerlendirmelerine ilişkin başlıklar görülmektedir. Özdeğerlendirme bakımından Ö2: "Diksiyon açı- 
sından kendimi olumlu görüyorum. Çünkü konuşurken birçok noktaya dikkat ederim... Diksiyonumun düzgün olduğunu düşünüyorum." diyerek diksiyona dikkat ederek konuştuğunu belirtmiştir. Ö2 özdeğerlendirmesine devam ederken: “... göz teması, jest ve mimiklere dikkat ederim. ... Şive kullanmadan İstanbul Türkçesi kullanırım." ifadesiyle ayrıntılara dikkat ettiğini belirtmiştir. Ö4: “...Bazı kelimeleri yuvarlayarak söylüyorum. Ama genelde Türkçeyi düzgün kullanmaya özen gösteriyorum. Mesaj yazarken bile kelimeleri tam olarak yazmaya çalışıyorum." şeklinde görüş belirterek Türkçeyi doğru ve düzgün kullandığını, aynı zamanda yalnızca konuşmada değil yazmada da bu özeni gösterdiğini vurgulamıştır. Diksiyon konusunda kendini olumlu olarak değerlendiren bir başka öğretmen adayı Ö42 ise: "Konuşma yaparken ses tonumu iyi kullandığımı düşünüyorum. Aynı zamanda kelimelerin telaffuzlarına dikkat ediyorum." diyerek doğru telaffuz ve ses tonu konusunda yeterli olduğunu belirtmiştir. Ö13, "Diksiyonumun çok kötü olduğunu düşünmüyorum. Karşımdaki kişiye kendimi doğru ifade edebilirim." diyerek diksiyonu, karşıdaki kişi tarafından anlaşılabilir olma durumu olarak değerlendirmiştir.

Ö5: "Ben kendim herhangi bir şiiri ya da metni okurken elimden geldiğince diksiyon kurallarına uymaya çalışıyorum. Fakat bu konuda kendimi yeterli görmüyorum. Çok fazla eksiğim var." görüşüyle metin okumada diksiyona dikkat ederek özdeğerlendirme açısından olumlu yaklaştığını ancak tam olarak bu konuda kendini yeterli görmediğini belirtmiştir. Benzer biçimde Ö16: "Kendim kitap okurken ya da şiir okurken noktalama işaretlerine dikkat edip ona göre okuma yapıyorum. Sınıfta ders anlatırken de buna dikkat ediyorum. Yalnız diksiyonu doğru şekilde yapmak için de doğru nefes almak gerekli. Bu da bende bir eksiklik, çünkü sınıfta sunum yaparken tıkandığım ya da kelimeleri doğru söyleyemediğim oluyor." görüşüyle de okuma konusunda dikkat ettiğini, ancak nefes kullanmada kendini yetersiz gördüğünü belirtmiştir. Öğretmen adaylarından Ö10: "Diksiyonum iyi değil. Kendimi bu konuda geliştirmeliyim. Konuşurken kelimelerin vurgulanmasına ve ses tonuna dikkat etmeliyim." diyerek diksiyon konusunda kendisini sözcüklerin vurguları ve ses tonu konusunda geliştirmesi gerektiğini ifade ederek bu konudaki eksikliğinin farkında olduğunu vurgulamıştır. Ö21: "Şivemle konuşmayı seviyorum. Ama yazarken tabi bu böyle olmuyor." şeklindeki görüşüyle yazarken kurallara dikkat ettiğini belirtmiştir. Ö15: “...Üzgün olduğumda ya da heyecanlandığımda ses tonum, konuşma hızım farklılaşıyor. Fakat bazen de hızlı bir şekilde konuşma yapabiliyorum." görüşüyle hızlı konuştuğunu ifade ederken; öğretmen adaylarından Ö18, farkında olduğu ve yaptığı diksiyon hatalarına ilişkin olarak: "Konuşurken kelimeleri bazen de harfleri yutuyorum. Gülerken konuşuyorum. Heyecanım karşı tarafa yansıyor." şeklinde özdeğerlendirmesini yapmıştır.

Öğretmen adayları yanlış yaptıkları noktaları belirtirken aynı zamanda kendi diksiyonunu olumsuz etkileyen etmenleri de sıralamışlardır. Buna ilişkin olarak Ö32: "Peltek olduğum için diksiyonumun çok iyi olduğunu düşünmüyorum." şeklinde görüşünü belirte- 
rek, diksiyonundaki sorunun nedeni konusunda tespitte bulunmuştur. Ö11: "Konuşurken kendimi ifade etme, sözlü olarak ses tonu ve mimiklerimle birlikte, diksiyonumun iyi olduğunu düşünüyorum. Fakat eksiklik olarak yeterince kitap okumamış olmamdan kaynaklanabilir; kelime dağarcığımın yetersiz olduğunu düşünüyorum." diyerek diksiyonda kelime dağarcığının da önemli olduğunu vurgulamıştır. Öğretmen adaylarından Ö21: "Konuşurken diksiyon kurallarının açıkçası ne olduğunu bilmiyorum ve uymuyorum." diyerek olumsuz nedeni belirtmiştir. Ö43 utangaç olmanın diksiyon konusunda kendini doğru ifade etmeyi etkileyen olumsuz bir etmen olduğunu şöyle belirtmiştir: "Daha önce diksiyon kursuna gitmiştim. Ama bana pek yararı olduğunu düşünmüyorum. Ben içine kapanık, utangaç biriyim. $O$ yüzden toplum karşısında kendimi iyi ifade edemediğimi düşünüyorum." Bir başka öğretmen adayı akıcı konuşamama nedenini Ö40: "Konuya hakim olduğumda konuşurum, fakat hakim olmadığım bir konuda çok düşünürüm, akıcı konuşamam

ve heyecanlanırım." şeklinde belirtmiştir. Öğretmen adaylarından Ö55 de: “...Arkadaş çevresindeki samimiyetten dolayı diksiyon biraz kaymakta..." diyerek arkadaş çevresindeki konuşmalarda diksiyonunun bozulduğunu vurgulamıştır.

Bu bağlamda öğretmen adaylarının bir kısmının kendilerini diksiyon konusunda yeterli gördükleri ve diksiyona dikkat ederek konuştukları, okudukları ve yazdıkları belirlenmiştir. Bunun yanı sıra öğretmen adaylarının diğer bir kısmının da kendilerini diksiyon konusunda yetersiz gördükleri, eksikliklerinin farkında oldukları ve kendilerini geliştirmeleri gerektiği görüşünü benimsedikleri bulgusuna ulaşılmıştır.

\subsection{Eğitim Alma}

Araştırmada son olarak, öğretmen adaylarına "Diksiyonla ilgili nasıl bir eğitim almak isterdiniz?" sorusu yöneltilmiştir. Buna ilişkin olarak öğretmen adaylarının verdikleri yanıtlar incelendiğinde ortaya çıkan tema ve alt temalar Şekil 4'te gösterilmiştir: 

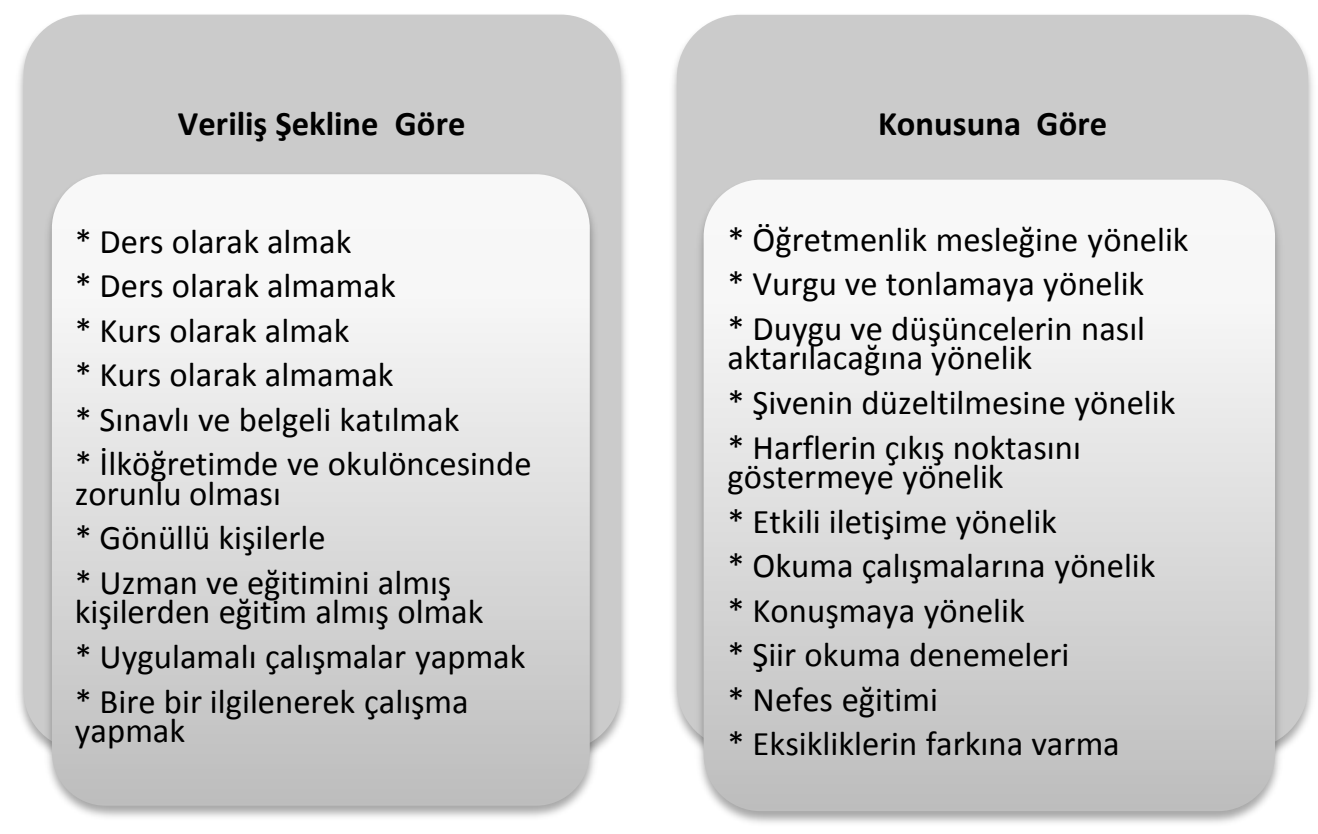

Şekil 4. Eğitim Alma Teması

Şekil 4 incelendiğinde, öğretmen adaylarının eğitim alma isteklerinin "veriliş şekli" ve "konusuna" göre farklılık gösterdiği görülmektedir. Öğretmen adaylarından Ö44: “...ders olarak verilmesini isterdim..." diyerek görüşünü belirtirken; Ö2: "Diksiyonda ders olarak eğitim almak isterdim. Çünkü eğitimde sınav oluyor. Ancak kursla çok fazla sınava önem verilmiyor." şeklinde eğitim alma isteğini belirtmiştir. Buna karşın öğretmen adaylarından Ö25: "...Kişisel gelişim kursunda bunun daha detaylı yapılacağını düşünüyorum. Ders olarak yapıldığında çok fazla katkısı olmuyor." ifadesiyle, diksiyonla ilgili kurslara katılmak istediğini belirtmiştir. Bir başka öğretmen adayı Ö18: "Halk eğitim kursundaki eğitimi almak isterim. Öğretmenlik için Türkçe (Sözlü Anlatım) dersinde diksiyon eğitimi almak isterim." şeklinde görüşünü belirterek hem derste hem kursta diksiyon konusunda bir eğitim almak istediğini ifade etmiştir.

Ö6: "Okulda almak isterdim. Öğretmenlerin tek tek ilgileneceği şekilde." diyerek bire bir çalışmalar yapmaya dikkat çekerken; Ö39: “...Her şeyi uygulamalı bir şekilde gösteren, öğrenci üzerinde duran bir ders almak isterim." ifadesiyle bire bir uygulamalı çalışmaların 
önemini ifade etmişlerdir. Ö49 diksiyonda verilen eğitimi uzman kişilerin vermesi gerektiğini: "Bu alanda eğitimli birinden ders almak isterdim..." şeklinde belirtmiştir. Öğretmen adaylarından Ö45 ise: “...ilköğretim veya okulöncesinde zorunlu olmalı" şeklinde görüşünü belirtmiştir. Verilen yanıtlar bağlamında; öğretmen adaylarının ders ya da kurs biçiminde bir diksiyon eğitimi almak istedikleri; bu eğitimin uzman kişilerce ve uygulamalı olarak gerçekleşmesi gerektiği söylenebilir.

Öğretmen adayları, diksiyona ilişkin bir eğitim almak istediklerinde hangi konulara ağırlık verilmesi gerektiğini görüşlerinde belirtmişlerdir. Bu başlıkla ilgili olarak Ö14: "Duygu ve düşüncelerimizi nasıl aktaracağımızın öğretilmesi, olması gerek. Konuşma şeklinin öğretilmesi ve öğretmenlik mesleğinde en iyi şekilde nasıl öğretileceğinin gösterilmesini isterdim." diyerek duygu ve düşünceleri ifade etme ve konunun öğretmenlik açısından ele alınmasına değinmiştir. Öğretmen adaylarından Ö31: "Eksikliklerimi giderecek şekilde olmasını; şive konusunda ve vurgu-tonlamalara dikkatimi artıracak bir eğitim almak isterdim." şeklinde görüşünü belirtmiştir. Bir başka öğretmen adayı Ö41: "Daha iyi konuşmak için bir topluluk önünde rahat olabilmek için doğru nefes alıp verme ve kelimelerin doğru vurgulanışı ile ilgili eğitim almak isterdim." diyerek isteğini ifade etmiştir. Öğretmen adaylarından Ö32: "Harflerin çıkış noktasına kadar söylenişini öğreten bir eğitim"; Ö48: "...etkili iletişimi geliştirecek...bir eğitim"; Ö15: "Diksiyonla ilgili sadece okumaların yapıldığı, okuma inceliklerinin uygulama yapılarak öğretildiği hatta vurgulamanın şiir üzerinde gösterildiği bir eğitim" şeklindeki görüşleriyle diksiyonla ilgili nasıl bir eğitim istediklerini belirtmişlerdir.

Bu açıdan ele alındığında, öğretmen adaylarının bir kısmının diksiyonu, bir ders ya da kurs şeklinde almak istedikleri; uzman kişilerce ve uygulamalı olarak mesleğe yönelik, vurgu-tonlamaya dikkat eden, nefes almayı ve şive kullanımını düzelten şekilde öğrenmek istedikleri bulgusuna ulaşılmıştır.

\subsection{Seslendirmede Yapılan Hatalar}

Öğretmen adaylarına; "Size göre aşağıdaki seçeneklerden hangisinin kullanım şekli doğrudur?" şeklinde kapalı uçlu sorulardan oluşan bir bölüm sunulmuştur. Bu bölümde diksiyonun konuşma-okuma-seslendirmeyle ilgili temel kurallarına ilişkin ifadelerin öğretmen adaylarına göre doğru/yanlış kullanımları belirlenmiştir. Kapalı uçlu sorular Şekil 5 'te gösterilmiştir: 
Konuşurken ya da okurken, sizce nasıl söylenir?

Yazılışı: Ağlamayacak mıyız?

Okunuşu:
a) Ağlamıcak mıyız?
b) Ağlamayıcak mıyız?
c) Ağlamıyıcak mıyız?

Yazılışı: Sürüneceğiz

Okunuşu:
a) Sürünücez
b) Sürüncez
c) Sürünüceez

Yazılışı: Söyleyen

Okunuşu:

a) Söylüyen

b) Söyliyen

c) Söyleyen

Yazılışı: Bağırdı

Okunuşu:

a) Baırdı

b) Bağardı

c) Baardı
Yazılışı: Değil

Okunuşu:
a) Diğil
b) Değil
c) Diil

Yazılışı: Beğendirmek

Okunuşu:
a) Beyendirmek
b) Beendirmek
c) Beğendirmek

Sizce vurgu hangi hecededir? Vurgu olduğunu düşündüğünüz hecenin altındaki kutucuğu işaretleyiniz.
A-lan-ya
Bur-sa
Hin-dis-tan
ar-ka-daş-lar
Ah-met sim-si-yah

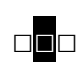




\section{Sizce hangi ifade doğrudur?}
a) İzmir eski valisi
b) İzmir'in eski valisi

Şekil 5. Seslendirmede Yapılan Hatalar Teması

Öğretmen adayları bazı sözcüklerin okunuşuna, vurgusuna ve uzatma işareti kullanıldığında anlamlarındaki farklıı̆ı̆ belirlemeye yönelik Şekil 5'te belirtilen kapalı uçlu sorulara yanıt vermiştir. Buna göre öğretmen adaylarının, -ecek/acak eki alan sözcüklerde ünlü daralması yapmadan metinleri okudukları/seslendirdikleri belirlenmiştir. Bunun yanı sıra a+ğ+ünlü harf kalıbında a sesinin uzatılarak seslendirilmesi; e+ğ+ünlü harf kalıbında ise ğ sesinin y sesine dönüşmesine yönelik kullanımlarda da hatalar yaptıkları verdikleri yanıtlarla belirlenmiştir. Bu bağlamda öğretmen adaylarının diksiyonda ünlü harflerin aldıkları eklerle birlikte seslendirilmesine ilişkin yanlış bilgileri olduğu söylenebilir.

Öğretmen adaylarını çoğu, diksiyonda vurgu ve tonlama konusunda doğru yanıtlar vermişlerdir. Yer ve şehir adlarında, sonda yer alan eklerde ve özel adlarda vurgunun hangi hecede olduğuna dair doğru bilgilerinin olduğu belirlenmiştir. Uzatılarak seslendirilen bazı harflerin de anlam farkı oluşturduğuna ilişkin sorulara verdikleri yanıtlar incelendiğinde ise öğretmen adaylarının bir kısmının doğru yanıt verdikleri belirlenmiştir. Araştırmanın kapalı uçlu sorularına verilen yanıtlar, diksiyona ilişkin farkındalığı belirleyen ve özdeğerlendirme temasında toplanan yanıtları destekleyen veriler sunmuştur.

\section{Tartışma, Sonuç ve Öneriler}

Yapılan bu araştırma ile öğretmen adaylarının diksiyona ilişkin görüşleri; diksiyonun önemi, öğretmenlikte diksiyon, özdeğerlendirme, eğitim alma ve seslendirmede yapılan hatalar temaları altında ele alınmıştır. Araştırma sonuçlarına göre; sınıf öğretmeni adayları için diksiyon; bireyler, bireylerarası ilişkiler ve konuşma açısından önem taşımaktadır. Öğretmen adayları diksiyonu bireysel olarak kendini doğru ifade etme ve tanımada; bireyler arası ilişkilerde ise iletişim kurma, sosyalleşme, karşıdakini anlama ve toplumda dikkat çekme bakımından yararlı bulmaktadırlar. Topçuoğlu ve Özden (2018) güzel konuşmanın bir sanat olduğunu, güzel konuşan kişilerin çevrelerindeki insanları kısa sürede etkileme ve kendi duygu ve düşüncelerini ifade edebilme gücüne sahip olduğunu vurgulamaktadır. Bu yönüyle araştırmaya katılan öğretmen adaylarııı iletişim kurma, kendini ifade etme ve saygınlık bakımından diksiyonu yararlı bulduklarını söylemek mümkündür. 


\section{Emel GÜVEY AKTAY}

Araştırmada öğretmen adaylarının akıcı konuşabilme, doğru telaffuz ve Türkçeyi doğru konuşma konusunda da diksiyonu önemli gördükleri ortaya çıkmıştır. Öğretmen adaylarının diksiyonu önemli bulması, Karakelle'nin (2005) yaptığı çalışmada süreçteki öğretmenler tarafından da önemli görülmektedir. Çalışmada öğretmenler, düzgün bir diksiyona sahip olmayı, beden dilini ve ses tonunu etkili kullanmayı, dile hakim olma ve bilgiyi etkili sunmayı, etkili öğretmen nitelikleri olarak tanımlamaktadır. Bu bağlamda, öğretmen adaylarının ve öğretmenlerin kısacası öğrenciyle etkileşim içerisinde olan kişiler için diksiyonun, oldukça gerekli bir yeterlik olduğu ifade edilebilir.

Araştırmaya katılan sınıf öğretmeni adaylarının diksiyonu, öğretmenlik mesleğinde etkili öğretmen özellikleri olarak açısından ele aldıkları ortaya çıkmıştır. Öğretmen adayları diksiyonu, öğrencilere rol model olma ve onların dikkatini derse çekme konusunda yararlı buldukları ortaya çıkmıştır. Bunun yanı sıra bir saygınlık ve otorite kazanma aracı olarak da gördükleri sonucuna ulaşılmıştır. Topçuoğlu-Ünal ve Sever (2014) de öğretmen adaylarıyla yaptıkları çalışmada, diksiyonun etkili iletişim kurmaya yardımcı olduğunu ve öğrencileri için daha iyi bir öğretmen olmayı sağladığını belirtmiştir. Bu bağlamda iyi bir diksiyonla öğretmenlerin, öğrencileri için birer rol model oldukları ve diksiyonun bu rol modeli etkilediği sonucu desteklenmektedir.

Araştırmada öğretmen adaylarının diksiyon konusunda kendilerini değerlendirmelerine yönelik sonuçlar incelendiğinde; öğretmen adaylarının bir kısmının diksiyona dikkat ederek konuştukları, bir kısmının ise bu konuda kendini olumsuz değerlendirdikleri ortaya çıkmıştır. Kendini diksiyon konusunda yeterli gören öğretmen adaylarının, Türkçeyi doğru ve düzgün konuşma, kendini karşıdakine doğru ifade etme, ses tonunu doğru ayarlama, jest ve mimiklere dikkat etme, göz teması kurma, yazarken kurallara dikkat etme, metin okurken dikkat etme, şive kullanmama ve doğru telaffuz noktasında diksiyona dikkat ettikleri ortaya çıkmıştır.

Buna karşın bazı öğretmen adayları ise kendilerini diksiyon konusunda olumsuz olarak değerlendirmiş, yaptıkları hatalar ve olumsuzluk oluşturan nedenleri sunmuşlardır. Öğretmen adaylarının görüşleri doğrultusunda şive kullanımı, konuşurken heyecanlanma, yanlış vurgu-tonlama, nefes alma, okuma, sözcükleri yuvarlama, harf yutma, hızlı konuşma ve gülerken konuşma konularında hatalar yaptıkları sonucuna ulaşılmıştır. Bunun yanı sıra sınıf öğretmeni adaylarının utangaç olma, diksiyon kurallarını bilmeme, peltek olma, konuya hâkim olmama, arkadaş çevresi ve kelime dağarcığının yetersizliği nedeniyle diksiyonlarının iyi olmadıklarını düşündükleri ortaya çıkmıştır. Benzer biçimde Çalışoğlu'nun (2015) yaptığı çalışmada sınıf öğretmeni adaylarının konu anlatımı sırasında diksiyonlarının bozuk olduğunu fark ettikleri ve bu konuda eksikliklerini tespit ettikleri ortaya çıkmış- 
tır. Bu açıdan ele alındığında öğretmen adaylarının diksiyon konusunda kendilerini yetersiz gördükleri söylenebilir.

Araştırmada olumsuz durumlar oluşturan nedenler arasında öğretmen adaylarının konuya hakim olmadığı durumlarda akıcı konuşamadıkları ortaya çıkmıştır. Ayrıca öğretmen adaylarının hızlı konuştukları, konuşurken heyecanlandıkları belirlenmiştir. Akkaya (2012), konuşma hatalarına ilişkin araştırmasında, öğretmen adaylarının vurgu ve tonlamadan kaynaklı sorun yaşadıkları; hızlı konuştukları sonucuna ulaşmıştır. Akkaya (2012) bu sonuçlara göre konuşurken heyecanlanmayı psikolojik nedenlere dayalı; akıcı konuşamamayı ise konuşma duraksaması olarak değerlendirmiştir. Psikolojik nedenlerle ilgili olarak Yüksel (2002), Henderson ve Zimbardo'nun (1998) sınıfladığı utangaçlık semptomlarını ele almıştır. Buna göre utangaçlık semptomları ve psikomotor belirtiler arasında göz temasında kaçınma, alçak sesle konuşma, konuşma akıcılığındaki bozukluklar vb. durumların yer aldığını belirtmiştir.

Kelime dağarcığının yetersiz olmasının da araştırmada öğretmen adaylarının kendilerini diksiyon konusunda eksik görmelerinin bir nedeni olarak sunulmuştur. Sevim ve Varışoğlu (2012), araştırmalarında kelime dağarcığının öğretmen adayları için beşinci sırada yer alan bir konuşma sorunu olduğunu ortaya koymuştur. Kana (2015), Türkçe öğretmen adaylarıyla yaptığı çalışmasında da benzer sonuçlara ulaşmıştır. Buna göre, öğretmen adaylarının kelime hazinelerinin eksik olduğu ortaya çıkmıştır.

Öğretmen adaylarının diksiyona ilişkin özdeğerlendirmeleri sonrasında, geliştirmek istedikleri konularda eğitime intiyaç duydukları sonucuna ulaşılmıştır. Araştırmada öğretmen adaylarının bir kısmının diksiyonla ilgili ders ya da kurs almak istedikleri ortaya çıkmıştır. Ergin, Akseki ve Ergin (2012) çalışmalarında sınıf öğretmenlerinin, görev yaptığı süre içerisinde iletişim ve halk danslarından sonra en çok diksiyon konusunda eğitim almak istediklerini tespit etmiş ve bu konuda sınıf öğretmenlerinin hizmet içi eğitim alma gereksinimleri olduğu sonucuna ulaşmışlardır. Işık ve Erdem (2016) çalışmalarında, Türkçe öğretmenlerinin de benzer görüşte olduklarını belirtmişlerdir. Buna göre yalnızca sınıf öğretmenlerinin değil farklı branşlardaki öğretmenlerin dahi diksiyon konusunda kendilerini geliştirmek istediklerini söylemek mümkündür.

Bu bağlamda ileride yapılacak araştırmalar için öğretmen adaylarının yanı sıra öğretmenlerin de görüşlerini alan çalışmalar yapılabilir. Öğretmen adaylarına diksiyon konusunda gerekli eğitim verildikten sonra ileride, öğretmenlik mesleği sürecinde bu beceriyi nasıl kullandıklarını belirlemeye yönelik daha boylamsal çalışmalar gerçekleştirilebilir. Böylece rol model olan öğretmenlere, yaşamlarında kullanabilecekleri ve öğrencilerine aktarabilecekleri bir konuşma eğitiminin verilmesi sağlanmış olacaktır. 
Emel GÜVEY AKTAY

\section{Kaynaklar}

Akkaya, A. (2012). Öğretmen adaylarının konuşma sorunlarına ilişkin görüşleri. Mustafa Kemal Üniversitesi Sosyal Bilimler Enstitüsü Dergisi, 9(20), 405-420.

Bağcı-Ayrancı, B. (2016). Konuşma, konuşma eğitimi ve Türkçe programlarındaki yeri. Karaelmas Journal of Educational Sciences, 4, 15-24.

Canbulat, M. ve Kutluca-Canbulat, A. N. (2015). Avusturya ve Türkiye'de öğretmen adayı belirleme süreci. Pegem Eğitim ve Öğretim Dergisi, 5(1), 113-132.

Çalışoğlu, M. (2015). Sınıf öğretmeni adaylarının öğretim teknolojileri ve materyal tasarımı dersine ilişkin görüşleri. Current Research in Education ,1(1), 23-32.

Erdem, i. ve Deniz, K. (2008). Güzel konuşma kurslarında verimliliği artırmaya yönelik bir alan araştırması. Mustafa Kemal Üniversitesi Sosyal Bilimler Enstitüsü, 5(10), 75-90.

Ergin, İ., Akseki, B. ve Deniz, E. (2012). Illköğretim okullarında görev yapan sınıf öğretmenlerinin hizmet içi eğitim ihtiyaçları. Elektronik Sosyal Bilimler Dergisi, 11(42), 55 66.

Güneş, F. (2007). Türkçe öğretimi ve zihinsel yapılandırma. Ankara: Nobel Yayın Dağıtım.

Halvaşi, B. (2015). Ses eğitimcisi bakışı ile etkili ve doğru konuşma. International Journal of Social Sciences and Education Research, 1(3), 862-870.

Işık, R. ve Erdem, i. (2016). Türkçe öğretiminde karşılaşılan sorunların öğretmen görüşlerine göre belirlenmesi (Muş İli Örneği). Turkish Studies International Periodical for the Languages, Literature and History of Turkish or Turkic, 11(3), 1309-1332.

İnan, M. D. (2016). Güzel konuşma sanatı. Antalya: Nokta E-Book International Publishing.

Kana, F. (2015). Öğretmen adaylarının Türkçeyi doğru, güzel ve etkili kullanma becerisiyle ilgili görüşleri: bir durum çalışması. Eğitimde Kuram ve Uygulama, 11(4), 1336-1355.

Karakelle, S. (2005). Öğretmenlerin etkili öğretmen tanımlarının etkili öğretmenlik boyutlarına göre incelenmesi. Eğitim ve Bilim, 30(135), 1-10. 
Katrancı, M. (2014). Öğretmen adaylarının konuşma becerisine yönelik öz yeterlik algıları. Bartın Üniversitesi Eğitim Fakültesi Dergisi, 3(2), 174 - 195.

Lincoln, Y.S. ve Guba, E.G. (1985). Naturalistic inquiry. California: Sage Publications.

Merriam, S. B. (2013). Nitel araştırma desen ve uygulama için bir rehber. S. Turan (Çev.Ed.). Ankara: Nobel Yayınevi.

Milli Eğitim Bakanlığı (2017). Öğretmenlik mesleği genel yeterlikleri. http://oygm.meb.gov.tr/meb_iys_dosyalar/2017_12/11115355_YYRETMENLYK_ME SLEYY_GENEL_YETERLYKLERY.pdf adresinden alınmıştır.

Milli Eğitim Bakanlığı (2017). Sınıf öğretmeni özel alan yeterlikleri. http://oygm.meb.gov.tr/meb_iys_dosyalar/2017_11/06160532_8YYretmen_Yeterlik leri_KitabY_sYnYf_YYretmenliYi_alan_yeterlikleri_ilkYYretim_parYa_11.pdf adresinden alınmıştır.

Sevim, O. ve Varışoğlu, B. (2012). Öğretmen adaylarının temel dil becerilerinde yaşanan sorunlarla ilgili düşünceleri: Atatürk Üniversitesi örneği. Gaziantep University Journal of Social Sciences, 11(4), 1042-1057.

Taşer, S. (2000). Konuşma eğitimi. İstanbul: Papirüs Yayınevi.

Thornbury, S. (2012). Speaking instruction. A. Burns \& J. C. Richards (Eds.). The cambridge guide to pedagogy and practice in second language teaching içinde (ss. 198-207). NY: Cambridge University Press.

Topçuoğlu-Ünal, F. ve Özden, M. (2018). Diksiyon ve konuşma eğitimi. Ankara: Pegem A Yayıncılık.

Topçuoğlu-Ünal, F. ve Sever, A. (2014). Candidate mother tongue teachers' perceptions on speech skills. Anthropologist, 17(1), 113-119.

Yıldırım, A. ve Şimşek, H. (2013). Sosyal bilimlerde nitel araştırma yöntemleri. Ankara: Seçkin Yayıncılık.

Yüksel, G. (2002). Üniversite öğrencilerinin utangaçlık düzeylerini etkileyen faktörler. G.Ü. Gazi Eğitim Fakültesi Dergisi 22 (3), 37-57. 